\title{
THE PROTOPLASMIC CORTEX IN RELATION TO STIMULATION ${ }^{1}$
}

\section{W. L. WILSON AND L. V. HEILBRUNN}

Dept. of Physiology and Biophysics, College of Medicine, University of Vermont, Burlington, Vermont, and Dept. of Zoology, University of Pennsylvania, Philadelphia 4, Pa.

In spite of the fact that the protoplasmic cortex is undoubtedly a most important part of the cell, little is known concerning its physical properties and how these may change during the life and activity of the cell. Typically, living cells consist of a mass of fluid protoplasm surrounded by a stiff layer of protoplasm just underneath the cell membrane. This stiff layer constitutes the cortex. A recognizable cortex has been described for ameba and for various types of marine egg cells. Such a cortex also exists in striated muscle cells (Rieser, 1949), and there is a likelihood that all cells have a cortex. In a marine egg cell the organization of the embryo and the course of development may well depend on the physical arrangement of the cortex, for this is often the only part of the egg protoplasm that is firm, and it is difficult to conceive of organization in a highly fluid mass of material. In irritable cells, the cortex may be the sensitive portion of the living structure. This would be a logical enough assumption, for the outer portion of the protoplasm presumably would be the first to become affected by external stimuli.

The colloidal theory of stimulation and response states that typically the first action of a stimulating agent is on the cortex of the cell. The stimulus causes a release of bound calcium from the cortex and this calcium passing into the cell interior causes changes in the protoplasm there. The evidence for this theory is many-sided and need not be discussed here (see Heilbrunn, 1951, for a recent summary). In the ameba, it is certain that various types of stimulating agents do cause a liquefaction of the cortex, and this liquefaction is thought to be associated with a release of calcium ion. But a weakness of the colloidal theory lies in the fact that it is only in the ameba that such changes in the cortex have actually been observed. This is due to the fact that although various types of cells are known to have a cortex, this cortex is ordinarily so stiff that it can not readily be studied.

Fortunately the egg of the worm Chaetopterus pergamentaceus has a cortex with easily visible granules and these can be moved by centrifugal forces not violent enough to break the cell. By measuring the amount of centrifugal force necessary to move granules out of the cortex, it is possible to estimate the stiffness of the cortical gel under one condition or another (compare Heilbrunn, Wilson and Harding, 1951, and especially Wilson, 1951).

We were interested in finding out first whether the cortex of the Chaetopterus egg cell was similar in its properties to the cortex of the ameba. The ameba cortex is liquefied by agents which tend to remove calcium from it (oxalates or potassium salts); it becomes stiffer in the presence of excess calcium. Likewise both heat and

1 This investigation was supported by a research grant from the National Cancer Institute, National Institutes of Health, Public Health Service. The work was done at the Marine Biological Laboratory, Woods Hole, Mass. 
cold cause a liquefaction of the ameba cortex; ultraviolet radiation has a similar effect, and so also do fat solvents. We wanted to know therefore whether or not the Chaetopterus egg cortex behaves in this manner.

Secondly in view of our belief that the response to stimulation which occurs when a cell is induced to divide as a result of treatment with various agents is similar to the response to stimulation which occurs generally in various types of irritable protoplasm, we thought that a proper study of the Chaetopterus egg cortex might help us to understand why it is that so many different types of agents can cause an egg cell to undergo division. It is true that in earlier publications an attempt has been made to interpret the initiation of cell division in terms of the colloid chemical theory of stimulation (see Heilbrunn, 1937, 1943, 1952). But when this earlier discussion was written, there was no direct evidence that an egg cell when it was exposed to a stimulating agent behaved like an ameba. The present study is an attempt to study that evidence.

We can say at the outset that our study has been successful from both standpoints. As we shall proceed to show, the cortex of the Chaetopterus egg does behave very much like the cortex of the ameba. And secondly we have found ample support for the view that initiation of cell division can be interpreted in terms of the colloidal theory of stimulation. For the most varied types of stimulating agents do cause both an initiation of division and a liquefaction of the cortex.

As in our earlier work (Heilbrunn, Wilson and Harding, 1951; Wilson, 1951) we estimated the stiffness of the cortex by determining the force necessary to move granules out of it. With the aid of an Emerson hand centrifuge, ${ }^{2}$ eggs were exposed to varying centrifugal forces for a minute. Then they were examined under high power of the microscope. Generally speaking, each of us examined ten centrifuged eggs, and from the twenty eggs observed we calculated the percentage of eggs which showed a definite movement of granules from the cortex. We made one series of tests for the eggs in the solutions whose effects we were testing and another series of tests for the control eggs in sea water. The end point was taken as that centrifugal force just sufficient to cause movement of granules from the cortex. In order to get this exact value, we usually resorted to interpolation. For example, if we found that turning the centrifuge 40 times in a minute caused $40 \%$ of the eggs to show movement of granules from the cortex, and turning the centrifuge handle 42 times in a minute caused $60 \%$ of the eggs to show movement of cortical granules, then the end point was taken as the force developed by turning the centrifuge handle 41 times per minute. No claim is made for the exactness of our values, but in every case repetition of the experiments gave us concordant results. One difficulty in performing the experiments arose from the fact that in the control eggs the rigidity of the cortex kept decreasing during the course of the experiment. In other words, as the eggs aged, the cortex became progressively less rigid. However, this was not a serious difficulty for we made measurements of the control eggs from time to time, so that the value finally recorded was the appropriate value for comparison with that of the experimental eggs.

The results of our studies are shown in Table I. This table does not give the time at which the measurements were made. In almost all cases the effect of the

2 These hand centrifuges can no longer be purchased from the Emerson Co., but they can be supplied at a reasonable price by Mr. J. A. Appenzeller of the Zoology Department of the University of Pennsylvania. 
environment on the cortex was rapid, so that probably time did not play much of a role in determining the magnitude or the nature of the effect. However, calcium chloride seems to be rather slow in its action, so that a pronounced effect of the calcium apparently does not occur until about half an hour or longer.

TABLE I

The effect of various agents on the rigidity of the protoplasmic cortex

$\begin{array}{lcc}\quad \text { Treatment } & \text { Experimental } & \text { Control } \\ \text { Potassium oxalate } & 1600 & 4000 \\ \quad(70 \text { pts. s.w. + } 30 \text { pts. } 0.35 M \text { K oxalate) } & & \\ \text { Potassium chloride }(0.53 M) & 1700 & 4400 \\ \text { Calcium chloride }(0.3 M) & 8400 & 6400 \\ \text { Sodium hydroxide (pH 9.34) } & 1200 & 3200 \\ \text { Ammonium hydroxide (pH 9.65) } & 600 & 5100 \\ \text { Hydrochloric acid (pH 3.78) } & 3900 & 6100 \\ \text { Ether }(2 \%) & 1400 & 5100 \\ \text { Butyl alcohol }(1.5 \%) & 1300 & 5600 \\ \text { Amyl alcohol }(0.5 \%) & 1600 & 6000 \\ \text { Heat }\left(38^{\circ} \mathrm{C} .\right) & 3200 & 5400 \\ \text { Cold }\left(0^{\circ} \mathrm{C} .\right) & 3000 & 4900 \\ \text { Ultraviolet } & 1100 & 4000\end{array}$

The table does not give information as to how the eggs were exposed and further detail is necessary. When eggs were placed in solutions containing potassium oxalate, they were washed at least once in the oxalate solution, so as to avoid the presence of too many oxalate crystals. Eggs exposed to potassium chloride solutions were washed several times in the solution; this was to get rid of traces of calcium. In studying the effect of sodium hydroxide, normal $\mathrm{NaOH}$ was added to sea water. Solutions of various $\mathrm{pH}$ 's were tested; pronounced effects were obtained with a solution having a $\mathrm{pH}$ of 9.34. Likewise, in studying the effect of ammonium hydroxide, solutions of varying $\mathrm{pH}$ were used. We are not prepared to state exactly how much alkalinity is necessary to produce a marked change in the cortex. With ammonium hydroxide, a $\mathrm{pH}$ of 8.9 does produce liquefaction, although this is not as pronounced as that which occurs in more alkaline solutions. In experiments with fat solvents we used as high a concentration as we could without destroying the eggs. Thus, for example, in our experiments with butyl alcohol, eggs treated with a $2 \%$ solution (by volume) broke up when centrifuged. A $1 \%$ solution had little effect on the eggs; a $1.5 \%$ solution had an effect without injuring the eggs too greatly. It should be noted that the concentrations of all fat solvents listed in the table are expressed as volume per cent.

In the heat experiments, a temperature of $36^{\circ} \mathrm{C}$. had about as much effect as did a temperature of $38^{\circ} \mathrm{C}$. In our experiments with cold, we found that moderately cold temperatures were without effect; only when eggs were exposed to temperatures near $0^{\circ} \mathrm{C}$. was the cortex markedly affected. In our experiments with ultraviolet, we used a powerful Uviarc lamp. This lamp gives off a whole spectrum of radiations, but we were concerned not so much with determining which wave lengths were effective or how much energy was involved, but rather with understanding what happened to the cortex when the eggs were stimulated by ultraviolet. However, we were careful to exclude the effect of heat. Accordingly, eggs to be irradiated were exposed in Stender dishes immersed in fingerbowls contain- 
ing cold sea water (at about $10^{\circ} \mathrm{C}$.). Under these conditions the sea water in the Stender dishes containing the eggs did not warm up above the room temperature. Eggs were exposed for 4 minutes; the target distance was 9.5 centimeters.

Let us now attempt to answer the first of the two questions we proposed for consideration. Are the properties of the gel in the cortex of the Chaetopterus egg similar to those of the gel in the cortex of the ameba? In ameba, potassium ion markedly decreases the viscosity of the cortical gel and calcium increases it (Heilbrunn and Daugherty, 1932). The gel in the cortex of the ameba tends to be liquefied by oxalate (Heilbrunn and Daugherty, 1933); the indication is that the Chaetopterus cortical gel acts in the same way, although the effect produced by potassium oxalate may have been due to potassium ion. Ether, butyl alcohol and amyl alcohol all tend to cause liquefaction of the Chaetopterus egg, just as they do in ameba (Daugherty, 1937). Cold and heat likewise exert a liquefying effect in both the cortex of Chaetopterus and that of ameba; ultraviolet likewise has a similar effect on both. There are no published data on the effect of alkali and acid on the cortex of ameba, but various workers in the Zoological Laboratory of the Univer'sity of Pennsylvania have shown in unpublished experiments that alkaline solutions cause a very marked decrease in the viscosity of the ameba cortex just as they cause a drop in the rigidity of the Chaetopterus cortical gel. Indeed, there appears to be only one point of difference between the behavior of the Chaetopterus cortex and the behavior of the cortex in ameba. Acid solutions cause a decrease in the rigidity of the Chaetopterus cortex. On the other hand, unpublished experiments indicate that acids have the opposite sort of an effect on the ameba cortex. On the whole, however, there is a marked similarity in the behavior of the two types of gels. Moreover, Berwick (1951) has shown that a fat solvent like ether causes a release of calcium from muscle brei, and Weimar (unpublished experiments) has found that cold, heat, ultraviolet and potassium all have a similar effect on brei from homogenized frog muscles.

Now as to the second of the questions we proposed. Stimulating agents (heat, cold, electric shocks, ultraviolet radiation) all cause a liquefaction of the cortex of ameba. And as is apparent from Table I they likewise all cause a sharp drop in the rigidity of the cortical gel in the Chaetopterus egg. Moreover, all the agents which stimulate the Chaetopterus egg to divide and begin its development cause a liquefaction of the cortex. Many years ago, Loeb (1901) showed that potassium ions cause an initiation of development in the Chaetopterus egg. We repeated these experiments with isotonic potassium chloride and again found that cleavage was initiated. In one experiment, a 14 minute exposure to a 0.53 molar potassium chloride solution gave $21 \%$ cleavage, and a 27 minute exposure gave $34 \%$ cleavage. Some of these cleavages look rather normal, but some might not have been true cleavages; it would not have been possible to decide without making cytological preparations.

Alkalies also can cause the initiation of cleavage and development in Chaetopterus. Something of this sort is mentioned by Loeb in his paper, but he is not sure whether the effect is due to alkali or to potassium ions. In one of our experiments in which eggs were kept in a solution of sea water to which sodium hydroxide had been added until the $\mathrm{pH}$ was $9.34,59 \%$ cleaved. These eggs had been subjected to the alkali for nearly 5 hours (292 minutes). In another experiment, there was a high percentage of cleavage in eggs left in solutions made alkaline with sodium 
hydroxide. The pH of these solutions was 8.67 and 8.96. Of all the parthenogenetic agents used by Loeb, the most successful were hypertonic solutions. We therefore were interested in trying to find out whether such solutions caused a liquefaction of the cortex. The evidence that we have indicates that they do. But the tests are complicated by two factors. In the first place, if strong hypertonic solutions are used, the interior protoplasm of the cell becomes so stiff that even vigorous centrifuging does not move the granules in the interior of the cell. Under these conditions the granules of the cortex can not properly be observed, for it is only when there is a hyaline zone free from granules that the cortex stands out as a distinct layer which can readily be studied. In the second place, hypertonic solutions cause a pronounced swelling of the cortical granules.

In our tests when $10 \mathrm{ml}$. of 2.5 molar sodium chloride was added to $90 \mathrm{ml}$. of sea water, no great amount of cleavage occurred. However, if $15 \mathrm{ml}$. of the hypertonic solution was added to $85 \mathrm{ml}$. sea water or when $20 \mathrm{ml}$. of the hypertonic solution was added to $80 \mathrm{ml}$. of sea water, high percentages of parthenogenetic development were obtained. In one experiment eggs were exposed to $15 \mathrm{ml}$. of 2.5 molar sodium chloride plus $85 \mathrm{ml}$. sea water for 13, 24, 49, 69 minutes, and then returned to sea water. These exposures gave $34 \%, 38 \%, 57 \%$, and $58 \%$ cleavage, respectively. In this experiment a centrifuge test was made one minute after the cells were placed in the hypertonic solution. At this time, the cortex of the eggs exposed to the hypertonic solution was decidedly less rigid than the cortex of the control eggs in sea water. However, because of the factors mentioned above, no quantitative measure was possible.

Heat and cold can also cause the egg of the Chaetopterus to cleave. No great attempt was made to discover exactly which exposures gave the best results. In one experiment in which eggs were heated to $36^{\circ} \mathrm{C}$. and then allowed to cool slowly, 34\% of the eggs cleaved. Exposures to cold did not give such high percentages. In one experiment an exposure to $0^{\circ} \mathrm{C}$. for two minutes gave $11 \%$ cleavage; in another experiment, eggs exposed to $-0.5^{\circ} \mathrm{C}$. for two minutes gave $9 \%$ cleavage.

One thing is certain: all the agents which have been shown to cause initiation of cell division and initiation of development in the Chaetopterus egg cause a decrease in the rigidity of the cortex. But not all the agents which cause this change in the cortex are effective in initiating cleavage. This is due to the fact that some of the agents we tried are very toxic, and the eggs are killed by them before there is any chance for development.

The cortex of the Arbacia egg is much more difficult to study than is the cortex of the Chaetopterus egg. The cortical granules in the Arbacia egg are decidedly smaller than the cortical granules in the Chaetopterus egg. This makes them harder to see and it also makes them harder to move by centrifugal force, for according to Stokes' law the force required to move a particle varies as the square of the radius of the particle and thus the force required would be much greater for a small than for a large particle. We have made only a preliminary study of the cortex of the Arbacia egg, but our study has gone far enough to show that it has the same type of structure as the cortex of the Chaetopterus egg. In the Arbacia egg also, the cortex tends to be liquefied by oxalate and by ether. Moreover, just as in the Chaetopterus egg, the Arbacia cortex tends to become less rigid as the egg ages. 
Both in the Chaetopterus egg and under some conditions in the Arbacia egg, it is possible to move the cortical granules to one side of the cell. This makes possible a study of the influence these granules may have on the organization of the egg. In earlier centrifuge studies on egg organization it was possible to move only the granules in the egg interior. If, after suitable liquefying treatments, the granules of the cortex are moved also, this may have an important effect on the future development of the egg.

\section{SUMMARY}

1. The cortex of the Chaetopterus egg is made more rigid by excess calcium; it tends to lose its rigidity when exposed to oxalate solutions or to potassium ions.

2. The cortex of the Chaetopterus egg is also liquefied by acid, alkali, fat solvents, heat, cold, ultraviolet radiation and hypertonic solutions.

3. In general, the behavior of the Chaetopterus egg cortex is very like that of the cortex of ameba.

4. All agents which have been found to stimulate the Chaetopterus egg to divide cause a liquefaction of the cortex.

5. The results of this investigation lend additional support to the colloid chemical theory of stimulation.

\section{LITERATURE CITED}

Berwick, M. C., 1951. The effect of anesthetics on calcium release. J. Cell. Comp. Physiol., 38: $95-107$.

Daugherty, K., 1937. The action of anesthetics on amoeba protoplasm. Physiol. Zool., 10: $473-483$.

Heilbrunn, L. V., 1937. An outline of general physiology. W. B. Saunders Co., Philadelphia. 1st Ed.

Heilbrunn, L. V., 1943. An outline of general physiology. W. B. Saunders Co., Philadelphia. 2nd Ed.

Heilbrunn, L. V., 1951. The colloid chemistry of narcosis. In: Mécanisme de la Narcose (Colloques Internat. du Centre Nat. de La Recherche Sci.), pp. 163-178.

Heilbrunn, L. V., 1952. The physiology of cell division. In: Modern trends in physiology and biochemistry. Academic Press, N. Y. Pp. 123-134.

Heilbrunn, L. V., and K. Daugherty, 1932. The action of sodium, potassium, calcium, and magnesium ions on the plasmagel of Amoeba proteus. Physiol. Zool., 5: 254-274.

Heilbrunn, L. V., and K. Daugherty, 1933. The action of ultraviolet rays on amoeba protoplasm. Protoplasma, 18: 596-619.

Heilbrunn, L. V., W. L. Wilson and D. Harding, 1951. The action of tissue extracts on cell division. J. Nat. Cancer Inst., 11: 1287-1298.

Loes, J., 1901. Experiments on artificial parthenogenesis in annelids (Chaetopterus) and the nature of the process of fertilization. Amer. J. Physiol., 4: 423-459.

Rieser, P., 1949. The protoplasmic viscosity of muscle. Protoplasma, 39: 95-98.

Wilson, W. L., 1951. The rigidity of the cell cortex during cell division. J. Cell. Comp. Physiol., 38: 409-415. 


\section{$2 \mathrm{BHL}$ Biodiversity Heritage Library}

Wilson, W. L. and Heilbrunn, Lewis Victor. 1952. "THE PROTOPLASMIC CORTEX IN RELATION TO STIMULATION." The Biological bulletin 103, 139-144. https://doi.org/10.2307/1538412.

View This Item Online: https://www.biodiversitylibrary.org/item/17391

DOI: https://doi.org/10.2307/1538412

Permalink: https://www.biodiversitylibrary.org/partpdf/2319

\section{Holding Institution}

MBLWHOI Library

\section{Sponsored by}

MBLWHOI Library

\section{Copyright \& Reuse}

Copyright Status: In copyright. Digitized with the permission of the rights holder.

License: http://creativecommons.org/licenses/by-nc-sa/3.0/

Rights: https://biodiversitylibrary.org/permissions

This document was created from content at the Biodiversity Heritage Library, the world's largest open access digital library for biodiversity literature and archives. Visit BHL at https://www.biodiversitylibrary.org. 